ELORE (ISSN 1456-3010), vol. 15 - 1/2008.

Julkaisija: Suomen Kansantietouden Tutkijain Seura ry.

[http://www.elore.fi/arkisto/1_08/fin_c_1_08.pdf]

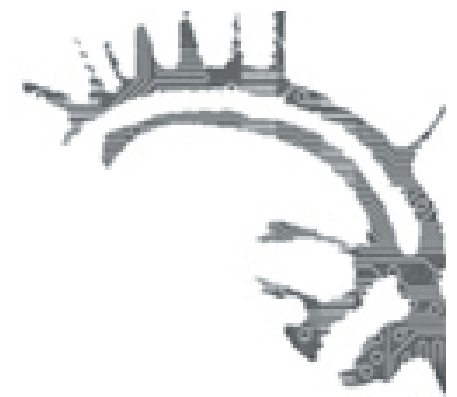

\title{
KIRJA-ARVIO:
}

\section{Kuva-Albumi Neuvosto-Karjalasta}

Hakamies, Pekka \& Fišman, Olga 2007: Unelma uudesta Karjalasta. NeuvostoKarjala valokuvissa 1920- ja 1930-luvuilla. Suomalaisen Kirjallisuuden Seuran Toimituksia 1068. Helsinki: Suomalaisen Kirjallisuuden Seura. 116 sivua.

\section{$\underline{\text { Outi Fingerroos }}$}

Pekka Hakamiehen ja Olga Fišmanin (Venäjän Etnografisen Museon Luoteis-Venäjän ja Volgan alueen osaston johtaja) kirjoittama ja kokoama kirja Unelma undesta Karjalasta on albumi, joka esittelee Venäjän Karjalaa ja sen kansankulttuurin muutosta 1920- ja 1930-luvuilla. Albumi sijoittuu siihen Karjalaan, joka perinteisesti on saanut visuaalisen ilmeensä I. K. Inhan kuvamateriaalin pohjalta. Hakamiehen ja Fišmanin albumi kuitenkin sisältää toisenlaisia utopioita. Uusi Karjala on kuvakertomuksessa sekä suomalaisen punaisen työkansan että Neuvostoliiton moderni unelma. Albumin ajallinen kehys on huikea, sillä kuvallinen kaari vaihtuu työkansan heimoideologiasta neuvostoideologian rakentamiseen.

Tekijät ovat koonneet albumin valokuvat, kaikkiaan 70 mustavalkoista otosta, Venäjän Etnografisen Museon kokoelmista. Kuvakertomusta taustoittavat Pekka Hakamiehen ja Olga Fišmanin kirjoittamat artikkelit. Näistä ensimmäinen, "NeuvostoKarjalan nykyaikaistuminen 1920- ja 1930-luvulla", on katsaus monisyisiin tapahtumiin takapajuiseksi ja jopa arkaaiseksi kuvatussa Karjalassa Venäjän vallankumouksen jälkeen. Artikkelissa "Karjalaisten historia ja kulttuuri valokuvissa 1920- ja 1930-luvuilla: tallennus, tutkimus ja nykyaika" Fišman puolestaan kiinnittää laajan kuvamateriaalin Hakamiehen rakentamaan kontekstikuvaukseen. Albumissa esitettävän kuvakertomuksen avainsanoiksi muodostuvat uusi Neuvostoliitto ja modernisaatio. 


\section{Kuva-Albumi Neuvosto-Karjalasta}

\section{Neuvosto-Karjala 1920- ja 1930-Luvuilla}

Pekka Hakamies kuvaa heti artikkelinsa alussa, miten Neuvosto-Karjala tuli alusta alkaen osaksi" "sitä uuden yhteiskunnan ja kulttuurin luomisen prosessia, jonka kommunistinen puolue käynnisti koko Neuvostoliitossa" (s. 10). Vallankumouksen ja kansalaissodan (1917-1922) jälkeen Karjala oli - ainakin hahmotelmissa - takapajuinen periferia, jossa väestön elinkeinoina olivat maanviljelys, pyynti ja kulkukauppa. Hakamies taustoittaakin, miten neuvostomodernisaatio istutettiin pimeän taikauskon viimeiseen pesäkkeeseen: Karjala tuli saattaa sivistyksen piiriin, talonpojista tehtiin työläisiä ja hankkeen suunnittelua varten perustettiin Gosplan. Suomalainen työväenaatteen airut Edvard Gylling perusti Karjalan työkansan kommuunin, josta sittemmin (1923) tuli Karjalan Autonominen Sosialistinen Neuvostotasavalta (Karjalan ASNT).

Hakamies kuvaa myös, miten neuvostomodernisaatioon ei kuulunut yksilöllistyminen eikä valinnan vapaus. Siten neuvostomodernisaatio oli paradoksi, jossa ihmisten elämää rajoittivat suunnitelmatalous, viisivuotissuunnitelmat ja työ kolhoosin hyväksi. Tätä ajanjaksoa on mielenkiintoista seurata myös Unelma undesta Karjalasta -albumin kuvista; kuvateksteissä "nuori nainen on lähdössä metsätöihin" (kuva 16), "kanadalainen (kanadansuomalainen) metsuri katkoo halkoja" (kuva 22) ja "traktori kyntää peltoa 'Pohjan pojat' -kommuunissa" (kuva 29). Työvoimaa Karjalan ASNT sai sekä muualta Neuvostoliitosta että Kanadan ja Yhdysvaltojen amerikansuomalaisista työläisten yhteiskunnan rakentajista. Hakamies onnistuukin kertomaan, miten karelianistinen Karjala muuttui Uuden talouden (NEP) Neuvosto-Karjalaksi, jossa praasniekkojen sijaan vietettiin "lepohetkiä pellolla" (kuva 33).

1930-luku oli Neuvosto-Karjalassa suunnitelmatalouden eli kollektiivitalouden, suurten tuotantoyksiköiden, erikoistumisen ja pakkosiirtojen aikaa. Ero edeltävään vuosikymmeneen oli suuri, sillä uskonto oli kiellettyä, kulutustavaroita ei saanut mistään ja elo kolhooseissa oli usein väritöntä. Karjalan ASNT:n rakentajista moni - Edvard Gylling mukaan lukien - sai kuolla kulakkien tavoin leireillä tai muuten vain epäselvissä olosuhteissa. Huolimatta suomalaisten punaisten nationalistien alueella kohtaamasta paradoksista (jota Markku Kangaspurokin (2000) kuvaa seikkaperäisesti teoksessaan Neuvosto-Karjalan taistelu itsehallinnosta) "Neuvosto-Karjala ja sen asukkaat ottivat sosialismin ensi vuosikymmeninä pitkän harppauksen kohti modernia yhteiskuntaa" (s. 28). Hakamies päättää artikkelinsa tähän toteamukseen eikä lähde penkomaan stalinismia ja vainoja sen tarkemmin. Tästä syystä elo Neuvosto-Venäjällä näyttäytyy kuvamateriaalinkin perusteella jotenkin inhimillisenä.

\section{KENTTÄTYÖTÄ, TUTKIMUSTA JA VALOKUVAUSTA Neuvosto-Karjalassa}

Olga Fišmanin artikkeli "Karjalaisten historia ja kulttuuri valokuvissa 1920- ja 1930luvuilla: tallennus, tutkimus ja nykyaika" on kiinnostavaa luettavaa. Unelma undesta Karjalasta -albumin kansatieteelliset valokuvat ovat ainutlaatuisia dokumentteja ajas- 


\section{OUtI FingerRoOS}

taan. Fišman käy läpi albumin kuvagallerian taustoja tarkastellen, miten Venäjän vuoden 1917 vallankumouksen jälkeen maahan muodostui opetus- ja kotiseutulaitosten verkko. "Pienet kansallisuudet" olivat ensi vaiheessa valistuneiden ja tieteentekijöiden kiinnostuksen kohteena, ja 1920-luvun kenttämatkojen tuloksia esitettiin näyttelyissä, konferensseissa ja aikakauslehdissä. Valokuvaus oli yksi pienten kansallisuuksien museaalisen tutkimustyön pääperiaatteista. Professori ja monien tutkimusmatkojen johtaja David Zolotarev perustelikin keruutyön tarpeellisuutta "elävällä elämällä":

Nyt on systemaattisesti rekisteröitävä ja tutkittava kaikkea uutta, joka ilmaantuu maalaiselämään joko väliaikaisesti tai tulevan elämänmuodon alkuituina. Nykyinen siirtymävaihe on meille erityisen kiinnostava, koska se antaa mahdollisuuden seurata välittömästi arkielämän muotojen muutosta, todentaa eri seikkojen vaikutuksen elämäntapaan ja panna merkille syitä, jotka johtavat erilaisten arkielämän ilmiöiden syntymiseen ja häviämiseen. (s. 36.)

Valokuvien osalta näiden 1920-luvun tutkimusretkien tulokset olivatkin mittavat. Karjala-aiheista kuva-aineistoa on arkistoitu Venäjän Etnografiseen Museoon 33 kokoelman ja 2411 numeron verran.

1930-luku toi Karjalassa kuvattuihin valokuviin uuden modernin Neuvostoliiton. Kokoelmiin nimittäin ilmestyi otsikko "uusi elämäntapa", johon sisältyi muiden muassa peltoviljely, sähköistäminen, liikenneyhteydet, pioneerit ja toimeenpanevien komiteoiden kokoukset. Kun 1920-luku oli suomalais-ugrilaisten kansojen kuvaamisen vaihetta, 1930-luku vei muiden muassa professori Zolotarevin syytteeseen suomalaisesta fasismista. Neuvostoetnografian ja museoiden tehtävänä olikin sosialistinen agitaatio ja neuvostotodellisuuden dokumentointi. Noina vuosina julkaistut matkakertomukset sisältävät"pakollisia aatteellisia arvioita ja leimoja" (s. 40). Samalla syntyi uusia Karjala-tutkimuksen aihelmia, kuten työläisten elämäkerrat, työläisfolklore ja kolhoosifolklore.

\section{AlbuMi ON KIINNOSTAVA KUVAKERTOMUS}

Unelma undesta Karjalasta -albumissa esitetty Neuvosto-Karjalan menneen kuvaus sinänsä ei sisällä mitään sellaista, jota Karjalasta jotain tietävä ei olisi esimerkiksi Markku Kangaspuron väitöskirjasta (2000) jo lukenut. Pekka Hakamies onnistuu kuitenkin artikkelissaan rakentamaan mukaansa tempaavan historiallisen kuvauksen, joka on albumin kuvien kannalta oivaltava. Artikkeli on myös tarpeellinen taustoitus Olga Fišmanin Neuvosto-Karjalassa tehtyä etnografiaa käsittelevälle tekstille, jota olisi ilman historiallista kehystä vaikea lukea ja ymmärtää. Itse valokuva-albumi kuvineen ei avautuisi ilman johdantoartikkeleita mitenkään. Hyvällä syyllä voi siis sanoa, että Hakamiehen ja Fišmanin kirja on juonellinen kertomus ja sillä on selkeä punainen 


\section{Kuva-AlBumi Neuvosto-Karjalasta}

lanka. Albumi on myös kansantajuinen dokumentti siitä perustutkimuksesta, jota yliopisto, museot ja arkistot kukin tahollaan tekevät.

Suomalaisen Kirjallisuuden Seuran kustannusosasto on onnistunut kuvaalbumin teknisessä toteutuksessa erinomaisesti: taitto on tyylikäs ja selkeä, kuvat on käsitelty taiten ja kovakantinen kirja itsessään on kiva esine omassa kirjahyllyssä.

\section{LÄHTEET}

KANGASPURO, MARKKU 2000: Newvosto-Karjalan taistelu itsehallinnosta. Nationalismi ja suomalaiset punaiset Neuvostoliiton vallankäytössä vuosina 1920-1939. Bibliotheca Historica 60. Helsinki: Suomalaisen Kirjallisuuden Seura.

Filosofian tohtori ja dosentti Outi Fingerroos on etnologian yliassistentti Jyväskylän yliopistossa. 